\title{
A REGULAMENTAÇÃO DOS SERVIÇOS PRESTADOS PELA STARTUP UBER NO BRASIL: O TRANSPORTE PRIVADO INDIVIDUAL DE PASSAGEIROS EM CONFORMIDADE COM OS PRECEITOS DE ACESSIBILIDADE DE UM ESTADO DEMOCRÁTICO
}

\section{THE REGULATION OF SERVICES PROVIDED BY STARTUP UBER: THE PRIVATE TRANSPORTATION OF INDIVIDUAL PASSENGERS IN ACCORDANCE WITH THE ACCESSIBILITY PRECAUTIONS OF A DEMOCRATIC STATE}

\author{
Paulo Henrique de Souza Freitas ${ }^{1}$ \\ Ricardo Utrabo Pereira ${ }^{2}$
}

\begin{abstract}
Resumo
O presente trabalho tem como objetivo inicial investigar a legislação referente ao transporte individual de passageiros, averiguando a possibilidade do ingresso de startups como a Uber neste mercado, que hoje é direcionado exclusivamente para táxis. Ocupa-se, em sua segunda parte, em verificar o impacto do ingresso de startups no mercado de transporte individual de passageiros e de que forma a atuação destas pode ser realizada de forma democrática, destacando-se o papel da acessibilidade para diversos grupos de pessoas. Portanto, com o presente estudo, pretende-se apontar formas de tornar o serviço de transporte individual de passageiros mais inclusivo. Para isso, recorreu-se ao método dialético para confrontar o modelo utilizado pelos táxis, com modelos decorrentes de startups como a Uber, os quais podem ingressar no mercado de transporte individual de passageiros de forma simultânea aos táxis. 0 resultado final, amparado em pesquisas e dados coletados indicam a possibilidade deste ingresso ser benéfico para os consumidores, permitindo meios de transporte mais democráticos e igualitários.
\end{abstract}

Palavras-chave: Regulamentação; Uber; Táxi; Estado Democrático; Acessibilidade.

\section{Abstract}

The present study has as an initial objective to investigate the legislation regarding individual passenger transportation, investigating the possibility of the entry of startups like Uber in this market, which is now exclusively aimed at taxis. In its second part, the paper examines the impact of the entry of startups in the individual passenger transportation market, and how these can be performed in a democratic state, highlighting the role of accessibility for different groups of people. Therefore, with the present study, it aims to identify ways of making the individual passenger transportation service more inclusive. For this, the dialectical method was used to confront the model used by taxis, with models derived from startups such as Uber, which can enter the individual passenger transportation market simultaneously with taxis. The final result, according to the research and the collected data, indicates the possibility of this entry being beneficial to consumers, allowing for more democratic and egalitarian means of transportation.

Keywords: Regulation; Uber; Taxi; Democratic State; Accessibility.

\footnotetext{
${ }^{1}$ Doutor em Direito Comercial pela PUC-SP. Professor Universidade Estadual do Norte Pioneiro (UENP) Jacarezinho. E-mail: paulo.freitas@freitasmartinho.adv.br

${ }^{2}$ Mestrando em Ciência Jurídica da UENP. E-mail: ricardoadv@gmail.com
} 


\section{INTRODUÇÃO}

O desenvolvimento de novas tecnologias da informação e da comunicação, relacionadas ao uso da internet, smartphones e tablets estão realizando transformações na forma de desenvolver as atividades diárias. Muitos mecanismos são criados para auxiliar as pessoas em situações do cotidiano, e alguns exercem grande influência na rotina, provocando relevantes transformações no mundo.

Um dos aplicativos que tem gerado grandes transformações sociais é o aplicativo desenvolvido pela startup Uber, o qual possibilita a prestação de serviços por motoristas particulares às pessoas que fazem uso do aplicativo, mediante remuneração. Em razão da semelhança da atividade com os serviços prestados pelos táxis, no mundo todo estão havendo grandes controvérsias acerca da constitucionalidade, da legalidade e dos benefícios que este aplicativo pode trazer à sociedade.

No Brasil, observa-se que há conflitos ideológicos, em que alguns (em especial os taxistas e aqueles que possuem licenças de táxis) pretendem a proibição do uso do aplicativo, e outros pretendem a regulamentação dos serviços prestados por startups como a Uber. Estes conflitos estão sendo gradativamente levados para o Poder Judiciário, e para os Poderes Legislativos locais.

Justifica-se o presente estudo na relevante função do Estado de evitar conflitos sociais, em especial através do uso de leis para regulamentar ou proibir condutas. Diante disso, o objeto do trabalho será analisar o serviço prestado pela startup e apontar se os seus reflexos são benéficos para a população.

Havendo possibilidade dos serviços prestados serem adequados para as pessoas, pretende-se analisar sobre a viabilidade constitucional para a regulamentação da matéria e qual é a competência para legislar sobre o tema, baseando-se o presente estudo, neste ponto, principalmente nos pareceres elaborados por José Joaquim Gomes Canotilho (2015) e Daniel Sarmento (2015).

Contudo, o principal objetivo a ser tratado no presente trabalho, diz respeito a uma matéria não abordada nos referidos pareceres, qual seja, a adequação dos serviços de transporte privado individual de passageiros sob uma perspectiva democrática, inclusiva, igualitária e que evite exclusões sociais.

Realiza-se, portanto, um estudo sobre o Estado Democrático, sobre a teoria da justiça elaborada por John Rawls e de que forma a Política Nacional de Mobilidade Urbana, assim como 
a acessibilidade urbana, podem atuar para reduzir a exclusão social. A partir deste exame, serão realizados apontamentos e sugestões de tópicos relevantes para constar em lei que regulamentem as atividades de serviços de transporte privado individual de passageiros, por entender que são paradigmas relevantes para a promoção de justiça social.

Para tanto, adota-se o método de abordagem dedutivo, pois a pesquisa parte de uma análise geral da legislação corrente e da doutrina para tentar obter uma possível solução para as situações concretas. Ademais, o procedimento empregado foi o monográfico, por intermédio de pesquisa bibliográfica voltada para os estudos relacionados ao tema.

\section{OS SERVIÇOS PRESTADOS POR TAXIS, UBER E SIMILARES}

As condições de deslocamento da população no espaço geográfico das cidades é fator de interesse público, sendo a questão prevista, inclusive, na Constituição brasileira, a qual prevê em seu Título VII, no Capítulo II, a regulamentação da política urbana, o que inclui a mobilidade urbana, abrangendo o trânsito de veículos e de pedestres, seja através do transporte individual, seja através do uso de transporte coletivo.

Por muitos anos o serviço de transporte motorizado de passageiros foi realizado exclusivamente por intermédio de táxis. Contudo, nos últimos anos, com o ingresso da startup Uber no mercado, houve um grande número de mudanças em todo o mundo, inclusive no Brasil.

Para o presente estudo, em um primeiro momento, é relevante compreender os serviços prestados pelos táxis, assim como pelo Uber, comparando as semelhanças e traçando as diferenças existentes entre ambos.

\section{Os serviços prestados por táxis}

A profissão de taxista é regulamentada pela Lei Federal no 12.468 de 2011, a qual reconhece a profissão de taxista em seu artigo 1o, e em seu artigo 2o prevê: "É atividade privativa dos profissionais taxistas a utilização de veículo automotor, próprio ou de terceiros, para o transporte público individual remunerado de passageiros, cuja capacidade será de, no máximo, 7 (sete) passageiros."

Assim, o que se observa no referido dispositivo é que os taxistas podem fazer uso de veículo automotor para realizar o transporte público individual remunerado de passageiros, cuja capacidade máxima será de, no máximo, 7 pessoas. 
Para realizar suas atividades são exigidos requisitos e condições previstas no artigo 3 da referida Lei, podendo-se citar, a título exemplificativo: a realização de diversos cursos; o atendimento do veículo às características exigidas pela autoridade de trânsito; a certificação específica para o exercício da profissão, entre outras.

Já, o artigo 5o indica os deveres dos taxistas, quais sejam: o atendimento aos clientes com presteza e polidez; vestir-se adequadamente para a função; a manutenção do veículo em boas condições de funcionamento e higiene; a manutenção regular da documentação do veículo exigida pelas autoridades competentes; e o atendimento aos ditames do Código de Trânsito Brasileiro.

Para realizar as suas atividades, os taxistas que atuam em cidades com mais de 50.000 habitantes devem instalar em seus veículos de trabalho os taxímetros, que é o "instrumento que baseado na distância percorrida e/ou no tempo decorrido, mede e informa gradualmente o valor devido pela utilização do veículo-táxi, independente da indicação de suplementos." (INMETRO, 1995, p. 02).

O que se observa, portanto, é que o funcionamento do taxímetro tem o objetivo de identificar quando o táxi está parado ou em movimento, sendo que em cada uma destas situações cobra-se uma tarifa predeterminada, de tal forma que o preço final da corrida será proporcional à distância percorrida e ao tempo de permanência no trânsito, acrescido do valor da tarifa inicial (bandeira inicial), e eventuais adicionais que variam de acordo com os municípios, tais como transporte de bagagem ou taxa de retorno (quando há corridas além da divisa dos municípios).

Para solicitar os serviços de táxis, os clientes possuem, basicamente, 3 formas, sendo estes os 3 segmentos que dividem o mercado de táxis: a) Táxi Rank, que ocorre quando os clientes pegam o táxi nos seus respectivos pontos; b) Hailing, que se realiza quando os clientes pegam o táxi em movimento na rua; c) Taxi-booking ou Phone-booking ou porta-a-porta, que consiste no pedido de táxi por telefone, por pré-agendamento (CADE, 2015, p. 20).

Esclarecidos as principais características que qualificam os táxis, passa-se a diferenciar estes dos serviços prestados por empresas privadas voltadas para o transporte individual de passageiros, como a startup Uber, assim como outras empresas em atividade no Brasil.

\section{Os serviços prestados pela startup Uber e assemelhadas}

Segundo o sítio da Uber (2016), a ideia da startup surgiu em Paris, numa tarde de neve, quando seus criadores, Travis Kalanick e Garrett Camp tiveram dificuldades em pegar um táxi. 
Em 2009 fundaram a Uber, realizando a oferta de serviços por intermédio de aplicativos a partir de 2010.

A partir deste período a startup passou a oferecer seus serviços em várias cidades do mundo, e atualmente presta serviços em 526 cidades. Ademais, atualmente a Uber é a startup mais valiosa do mundo, segundo tabela publicada no site statista (2016).

Canotilho define a startup nos seguintes termos (2015, p. 24):

De forma muito singela e abreviada, o "sistema Uber" consiste numa plataforma tecnológica que suporta uma aplicação móvel para smartphones. Com base nesta plataforma tecnológica oferece serviços ao mercado - às pessoas em geral e a "motoristas privados".

Através do "sistema app" e recorrendo a um serviço de geolocalização, liga os utilizadores aos "motoristas privados", sem ser necessário que o utilizador (consumidor) telefone ou se desloque do local em que se encontre. O simples acesso à app indica o número de automóveis mais próximos do local que utilizam o "sistema Uber", bem como o tempo estimado que demoram a chegar ao local em que o utilizador se encontre. Neste passo o utilizador escolhe o serviço que pretende: UberX ou UberBlack.

Basicamente, o que se observa é que os serviços prestados pela startup em muito se assemelham aos serviços de táxi, uma vez que realizam o transporte de passageiros ao local por eles pretendido, mediante pagamento, realizado proporcionalmente à distância percorrida e ao tempo de viagem, acrescido da tarifa inicial.

Contudo, há diferenças significativas entre ambos. Inicialmente, destaca-se a forma de solicitação dos serviços, pois só há uma forma de solicitar os serviços da Uber, qual seja, o ehailing. Segundo Marco Rogério Soranzo Cancián (2016, p. 24) “E-hailing é o processo de se pedir um carro, táxi, limusine ou qualquer outro tipo de transporte via plataforma virtual, computador ou algum dispositivo móvel." Ou seja, consiste basicamente, em uma forma de solicitação de transporte por intermédio de um dispositivo eletrônico, geralmente integrado a aplicativos de smartphones ou tablets. Nestes termos, observa-se que não existem "pontos" para o aguardo de passageiros, como os táxis possuem.

Outra distinção relevante consiste no pagamento, que não é feito diretamente ao motorista, como no caso do táxi, mas sim à plataforma da Uber, a qual extrairá o montante de $20 \%$ a $25 \%$ do valor pago, repassando o restante ao motorista. Observa-se, também, que a Uber não aceita pagamento por cartão de débito e que paulatinamente está sendo aceito pagamento em dinheiro no Brasil. 
É relevante mencionar, também, que em regra, os serviços prestados pela Uber são mais baratos que os serviços de táxi, seja na tarifa inicial, seja nos valores exigidos, em razão da distância percorrida ou do tempo exigido, conforme se observa na tabela a seguir³:

\section{Preços praticados por Táxis e pela Uber em São Paulo}

\begin{tabular}{|c|c|c|c|c|}
\hline & $\begin{array}{c}\text { Taxi comum } \\
\text { (bandeira 1) }\end{array}$ & $\begin{array}{c}\text { Taxi comum } \\
\text { (bandeira 2) }\end{array}$ & UberX & UberBlack \\
\hline Bandeirada & $\mathrm{R} \$ 4,50$ & $\mathrm{R} \$ 4,50$ & $\mathrm{R} \$ 2,00$ & $\mathrm{R} \$ 3,80$ \\
\hline Quilômetro rodado & $\mathrm{R} \$ 2,75$ & $\mathrm{R} \$ 3,58$ & $\mathrm{R} \$ 1,40$ & $\mathrm{R} \$ 2,32$ \\
\hline Minuto & $\mathrm{R} \$ 0,55$ & $\mathrm{R} \$ 0,55$ & $\mathrm{R} \$ 0,26$ & $\mathrm{R} \$ 0,28$ \\
\hline
\end{tabular}

No entanto é pertinente ressaltar que esta tabela utiliza o preço comum do Uber. Saliente-se que em horários de maior demanda, a Uber faz uso do denominado "preço dinâmico". Segundo informação extraída do site da Uber": "Se a demanda de passageiros estiver alta, o preço dinâmico aumentará os valores de modo gradual. Para os passageiros, o preço dinâmico ajuda a garantir a disponibilidade rápida de um veículo. Para os motoristas parceiros, o preço dinâmico aumenta os valores das viagens para fornecer um ganho adicional." Assim, nos períodos e locais em que houver alta demanda, os preços da tarifa serão majorados por intermédio de um multiplicador (definido pela Uber) conforme a oferta de veículos e a demanda de usuários.

Em termos de atendimento ao cliente, é notório que os motoristas da Uber oferecem balas e água aos seus passageiros, bem como que, ao final de cada viagem, o consumidor pode realizar uma avaliação sobre os serviços prestados pelo motorista podendo haver desligamento do motorista a critério da empresa.

Estas são algumas das principais diferenças em relação aos serviços prestados pela Uber e pelos táxis. Ainda serão apontadas outras diferenças em relacionadas aos incentivos e exigências decorrentes do Poder Público em relação aos táxis.

Cumpre esclarecer que há algumas startups que prestam serviços de transporte individual de passageiros, tais como: cabify; willgo; fleety; televo e T81. Não será feita uma análise pormenorizada de cada um destes aplicativos para não expandir demasiadamente o objeto de pesquisa.

\footnotetext{
3 Preços pesquisados pelo próprio autor em durante o mês de julho de 2016.

${ }_{4}^{4}$ Disponível em <https://help.uber.com/pt_BR/h/e9375d5e-917b-4bc5-8142-23b89a440eec>. Acesso em 03 de maio de 2017.
} 


\section{A natureza dos serviços prestados pela startup Uber}

Observa-se que, nos pareceres formulados por Canotilho (2015, p. 24) e por Daniel Sarmento (2015, p. 02) que a Uber consiste em uma "plataforma tecnológica", sem esclarecer de forma estrita qual a natureza dos serviços prestados pela Uber.

É importante destacar, no que tange à afirmação de que a Uber se trata de uma plataforma tecnológica, que existe grande controvérsia a respeito da natureza dos serviços prestados pela startup Uber, a qual gera um amplo rol de consequências para o mercado e para o Direito do Trabalho.

Embora o presente estudo esteja voltado para a situação da Uber no Brasil, é importante explorar e destacar relevantes documentos jurídicos emanados recentemente na Europa, podendo-se apontar a recente decisão proferida pelo Employment Tribunals ${ }^{5}$, (Tribunal do Trabalho do Reino Unido), o qual reconheceu, que o transporte é um dos ramos de atuação da Uber, a qual não se limita a prestar, somente, serviços tecnológicos, realizando, também, serviços de transporte.

Neste mesmo sentido posicionou-se o Advogado-Geral da União Europeia, no sentido de afirmar que a Uber possui natureza dúplice, prestando serviços de tecnologia, assim como serviços de transporte, como se extrai deste trecho de seu parecer:

Por conseguinte, a Uber não é um mero intermediário entre os condutores dispostos a oferecer serviços de transporte ocasionalmente e os passageiros em busca de tais serviços. Pelo contrário, a Uber é um verdadeiro organizador e operador de serviços de transporte urbano nas cidades onde tem presença. Embora seja verdade, como afirma Uber nas suas observações no caso, que seu conceito é inovador, essa inovação, no entanto, pertence ao campo do transporte urbano. ${ }^{6}$ (traduzido livremente pelo autor)

\footnotetext{
${ }^{5}$ REINO UNIDO. Employment Tribunals. Caso no 2202550/2015. Requerentes Y. Aslam, J. Farrar e Outros. Reclamadas: Uber B. V., Uber London Ltd., e Uber Britannia Ltd. 28 de out. de 2016. Disponível em <https://www.judiciary.gov.uk/wp-content/uploads/2016/10/aslam-and-farrar-v-uber-employmentjudgment-20161028-2.pdf>. Acesso em 21 de junho de 2017.

6 "61. Uber is therefore not a mere intermediary between drivers willing to offer transport services occasionally and passengers in search of such services. On the contrary, Uber is a genuine organiser and operator of urban transport services in the cities where it has a presence. While it is true, as Uber states in its observations in the case, that its concept is innovative, that innovation nonetheless pertains to the field of urban transport."

UNIÃO EUROPEIA. Tribunal de Justiça da União Europeia. Parecer do Advogado-Geral Maciej Szpunar. Caso no C-434/15. Requerentes: Asociación Profesional Elite Taxi. Requerida: Uber Systems Spain SL. 11 de maio de 2017.2 Disponível em $<$ http://curia.europa.eu/juris/document/document.jsf;jsessionid=9ea7d0f130d572e35b505c9940ddbfed cd9ffd192359.e34KaxiLc3eQc40LaxqMbN4PaxqLe0?text=\&docid=190593\&pagelndex=0\&doclang=EN\&m ode=Ist\&dir=\&occ=first\&part=1\&cid=734489>. Acesso em 21 de junho de 2017.
} 
Por outro lado revela-se importante esclarecer que, em recente decisão proferida pela 9a Turma do Tribunal Regional do Trabalho da 3a Região, foi declarada a inexistência da relação de emprego entre a Uber e o motorista reclamante, afirmando-se que a Uber é uma plataforma tecnológica que presta serviços de tecnologia, permitindo um contato direto entre consumidores e fornecedores, como se extrai do trecho a seguir:

Neste cenário é que surgem novos objetos de negócios e uso e ampliação de utilização de aplicativos como o Uber e o Airbnb (na área de hospedagem), por exemplo, que estabelecem contrato direto entre consumidores e fornecedores. E, também, não se pode olvidar que conseguem fomentar ganhos expressivos em eficiência, custo e comodidade nas transações para seus usuários. (Tribunal Regional do Trabalho da 3a Região, 2017, p. 13)

O presente trabalho não possui por objetivo desenvolver a análise desta questão de elevada complexidade, a qual se pretende avaliar em um estudo futuro, voltado especificamente para o exame das consequências do reconhecimento da natureza dos serviços prestados pela Uber.

Contudo, com base no parecer proferido em processo da União Europeia, assim como na decisão proferida pelo Tribunal do Trabalho do Reino Unido, tem-se, para o presente trabalho que os serviços prestados pela Uber possuem natureza dúplice, quais sejam, o de prestar serviços tecnológicos, assim como o de prestar serviços de transporte.

\section{Os conflitos decorrentes da diversidade do mercado e a necessidade de regulamentação estatal}

Como restou demonstrado, os serviços prestados pela Uber possuem muitas semelhanças com os serviços prestados pelos táxis, e embora hoje inexista viabilidade para a Uber atender todo o tipo de demanda que é direcionada aos taxistas ${ }^{7}$, houve grande revolta destes a partir do momento que a Uber passou a operar no Brasil, assim como na maior parte do mundo.

Desse modo, ao oferecer um serviço semelhante aos táxis, e cobrando valores inferiores aos dos serviços prestados por taxistas, a Uber despertou preocupação e críticas ao redor do mundo, em especial por parte dos taxistas, os quais viram sua exclusividade sobre o mercado de transporte individual de passageiros ameaçada a partir da entrada de uma concorrente no mercado (WISNIEWSKI e ESPOSITO, 2016, p. 65).

\footnotetext{
${ }^{7}$ v.g. como os pedidos realizados por telefone, ou nos pontos de taxi, e sempre que a pessoa não tiver à disposição de aparelho que possua o aplicativo.
} 
João Grandino Rodas (2016, s/p) apresenta os principais argumentos formulados pelos taxistas contrários aos serviços prestados pela Uber no país, nos seguintes termos:

ser ilegal a utilização do aplicativo por propiciar o transporte clandestino e não autorizado de passageiros; tratar-se de concorrência desleal, por não estarem os credenciados da Uber sujeitos a regulamentação e ao pagamento de impostos; favorecer o exercício ilegal da profissão de taxista por parte de motorista particular; e não ser o serviço da Uber tão diferenciado e barato como se propala.

Sobre os argumentos formulados pelos taxistas, o segundo capítulo deste artigo realizará uma análise acerca das questões diretamente relacionadas aos tópicos levantados, em especial com os três primeiros. O objetivo proposto ao mencionar os argumentos utilizados pelos taxistas refere-se à existência de diversos conflitos, em que é notório ver taxistas ofendendo, e até mesmo avariando, os veículos dos motoristas da Uber.

Assim, diante da instauração deste conflito, revela-se imprescindível que o Estado exerça sua função para o intuito de proibir ou regulamentar o exercício dos serviços prestados por motoristas da Uber. Ou seja:

Não basta que o Estado conheça a realidade, ele também deve agir para solucionar os conflitos sociais. Os avanços tecnológicos são produzidos numa escala impressionante de tempo e de quantidade e desafiam não só o Estado, como também a própria sociedade. (WISNIEWSKI e ESPOSITO, 2016, p. 68).

Por tais motivos, o presente estudo prossegue com o exame da viabilidade constitucional da regulamentação dos serviços prestados pela Uber e demais concorrentes, fazendo uma análise sob a perspectiva da lei 12.587 de 2012, a qual estabelece a Política Nacional de Mobilidade Urbana.

\section{A POLÍTICA NACIONAL DE MOBILIDADE URBANA E A CONSTITUCIONALIDADE DA PRESTAÇÃO DE SERVIÇOS DE TRANSPORTE PRIVADO DE PASSAGEIROS}

A divulgação de estudos e pesquisas referentes às condições de mobilidade urbana, em especial no que tange às condições das populações de baixa renda, fizeram com que o tema dos transportes públicos voltasse a ser importante objeto das discussões de políticas públicas (GOMIDE, 2006, p. 242)

Influenciada por este contexto, deve-se analisar a Constituição para verificar se há viabilidade para a regulamentação do transporte individual de passageiros, bem como verificar se a Lei 12.587 de 2012, a qual institui as diretrizes da Política Nacional de Mobilidade Urbana, regulamente o transporte individual de passageiros. 
Devem ser observados os fatores que possam oferecer melhora dos serviços de transporte e das condições de acessibilidade urbana da população, pois estes serviços possuem relevante papel para a efetivação das políticas sociais, uma vez que estes contribuem para o acesso das pessoas aos equipamentos básicos e para a igualdade de oportunidades (GOMIDE, 2006, p. 245-246).

\section{Viabilidade constitucional de regulamentação dos serviços de transporte individual de passageiros}

A questão proposta neste tópico refere-se a uma análise jurídico-constitucional acerca de eventuais causas de inconstitucionalidade de leis ou projetos legislativos que visam a proibição das atividades de motoristas parceiros da Uber, tendo por parâmetro a Constituição.

Para o exame proposto, toma-se por base que os princípios constitucionais são normas jurídicas que estabelecem limites para o legislador infraconstitucional e para a Administração, cuja inobservância enseja a invalidade das normas e dos atos que os contravenham. Ademais, os princípios constitucionais exercem influências fundamentais na interpretação da ordem jurídica (SARMENTO, 2015, p. 04).

Assim, o que se pretende analisar, sob uma perspectiva principiológica e constitucional, é se a Constituição possibilita que este transporte de passageiros seja realizado por motoristas que não sejam taxistas.

Para se obter esta resposta deve-se observar, preliminarmente, a inexistência de vedação constitucional sobre os serviços de transporte individual de passageiros. Acerca do tema dispõe o art. 182 da Constituição ${ }^{8}$, que define as diretrizes da política urbana e da mobilidade urbana. Pelo exame do referido dispositivo constata-se que a política de

\footnotetext{
${ }^{8}$ Art. 182. A política de desenvolvimento urbano, executada pelo Poder Público municipal, conforme diretrizes gerais fixadas em lei, tem por objetivo ordenar o pleno desenvolvimento das funções sociais da cidade e garantir o bem-estar de seus habitantes.

$\S 1$ O O plano diretor, aprovado pela Câmara Municipal, obrigatório para cidades com mais de vinte mil habitantes, é o instrumento básico da política de desenvolvimento e de expansão urbana.

$\S 20$ A propriedade urbana cumpre sua função social quando atende às exigências fundamentais de ordenação da cidade expressas no plano diretor.

$\S 3$ ㅇ As desapropriações de imóveis urbanos serão feitas com prévia e justa indenização em dinheiro.

$\S 4$ ํ É facultado ao Poder Público municipal, mediante lei específica para área incluída no plano diretor, exigir, nos termos da lei federal, do proprietário do solo urbano não edificado, subutilizado ou não utilizado, que promova seu adequado aproveitamento, sob pena, sucessivamente, de: I - parcelamento ou edificação compulsórios; II - imposto sobre a propriedade predial e territorial urbana progressivo no tempo; III - desapropriação com pagamento mediante títulos da dívida pública de emissão previamente aprovada pelo Senado Federal, com prazo de resgate de até dez anos, em parcelas anuais, iguais e sucessivas, assegurados o valor real da indenização e os juros legais.
} 
desenvolvimento urbano deve ser executada pelo Poder Público Municipal e que deve estar voltado para o desenvolvimento das funções sociais da sociedade e da garantia do bem-estar de seus habitantes. Assim, em nenhuma hipótese inviabiliza o transporte individual de passageiros.

Analisando-se a Constituição, ainda é possível observar que, em seu art. 21, XX, que compete à União instituir diretrizes para o desenvolvimento do transporte urbano e, nos termos do art. 22, IX, compete privativamente à União legislar sobre as diretrizes da política nacional de transportes.

A partir destes poderes conferidos à União, o Poder Legislativo Federal fez uso desta prerrogativa e elaborou a Lei 12.468 de 2011 e a Lei 12.587 de 2012, sendo que a primeira regulamenta a atividade dos taxistas, como já foi visto no primeiro capítulo e a segunda institui as diretrizes da Política Nacional de Mobilidade Urbana, a qual será objeto de estudo no item a seguir.

Assim, denota-se que na Constituição não existe vedação ao transporte individual de passageiros. A partir desta conclusão cumpre analisar se há elementos constitucionais que possibilitam a regulamentação destes serviços nos termos dos arts. 21, XX e 22, IX, ambos da Constituição.

Analisando os aspectos jurídicos que envolvem a startup Uber, Joaquim José Gomes Canotilho e Daniel Sarmento elaboraram pareceres favoráveis à regulamentação do aplicativo. Para formular este entendimento, basearam-se nos princípios constitucionais da livre iniciativa e da livre concorrência.

O princípio da livre iniciativa é um dos fundamentos da República Federativa brasileira, previsto no art. 1ㅇ, IV, e no art. 170, caput, ambos da Constituição. Este princípio confere à inciativa privada espaço de atuação na economia independente da atuação estatal. Ou seja, tem por objetivo garantir um desenvolvimento econômico sadio, livre de monopólios, ao passo que tutela o direito de inovar, criar investir e proporcionar à sociedade o direito de escolher os produtos e serviços que Ihes forem mais convenientes (WISNIEWSKI e ESPOSITO, 2016, p. 68).

Neste sentido, Daniel Sarmento (2015, p. 08-09) esclarece o conteúdo deste princípio indicando seus fundamentos essenciais e a liberdade de escolhas para os particulares se engajarem nas atividades econômicas que lhes interessam, resguardando-se os direitos de terceiros:

Pode-se dizer que a livre iniciativa repousa em dois fundamentos essenciais: trata-se de uma emanação relevante da liberdade individual, que também deve se projetar na esfera econômica; bem como de um 
meio voltado à promoção da riqueza e desenvolvimento econômico, em prol de toda a coletividade.

Em relação à proteção dos direitos do indivíduo, a ideia é de que os seres humanos têm projetos e fazem escolhas também no âmbito da sua vida econômica. A salvaguarda da sua liberdade e personalidade restaria incompleta se não fosse estendida a esta seara a garantia da sua autonomia, diante de pretensões autoritárias ou paternalistas do Estado. Daí porque, a regra geral deve ser a liberdade dos particulares para se engajarem em atividades econômicas, desde que não lesem direitos de terceiros ou interesses relevantes da comunidade.

Já o princípio da livre concorrência está previsto no art. 170, IV, da Constituição e está voltado para a proteção da liberdade de competição entre os agentes econômicos, garantindose uma disputa sadia no campo econômico entre os agentes que dele participam.

Nas palavras de Canotilho (2015, p. 05):

Efetivamente, uma atividade econômico privada é, por destinação, aberta a livre concorrência, isto é, ao pleno e livre acesso de todos. Neste sentido, uma ordem econômica fundada na liberdade de iniciativa econômica e no valor social do trabalho pressupõe ou implica a liberdade do mercado, isto é, pressupõe a liberdade de concorrência no acesso às atividades econômicas e no seu exercício.

E a livre concorrência é sadia à população em geral, pois a existência de diversidade de serviços possibilita a competitividade, o que gera maior eficiência produtiva das empresas, as quais buscam aperfeiçoar e reduzir os custos dos produtos e serviços que fornecem, visando prosperar no mercado, gerando melhora da economia (SARMENTO, 2015, p. 10).

Observa-se, também, a existência de precedente favorável à atividade praticada pela Uber e os motoristas à qual esta conecta, com fulcro nos princípios da livre concorrência e da livre iniciativa como se extrai da decisão de Apelação Cível e Reexame Necessário de no 0381371-80.2015.8.19.0001, proferida pela 13a Câmara Cível do Tribunal de Justiça do Rio de Janeiro em 22 de fevereiro de 2017:

ADMINISTRATIVO E CONSTITUCIONAL. MANDADO DE SEGURANÇA PREVENTIVO IMPETRADO POR MOTORISTA PROFISSIONAL, VISANDO ASSEGURAR O EXERCÍCIO DE ATIVIDADE LABORAL CONCERNENTE A TRANSPORTE INDIVIDUAL DE PASSAGEIRO, QUE É REMUNERADO ATRAVÉS DO APLICATIVO "UBER". CONCESSÃO DA SEGURANÇA. DECISÃO ESCORREITA, PORQUANTO EM CONSONÂNCIA COM AS NORMAS CONSTITUCIONAIS QUE DECLARAM E RECONHECEM O VALOR SOCIAL DO TRABALHO E A LIVRE INICIATIVA COMO PRINCÍPIOS FUNDANTES DA REPÚBLICA (ART. 1ㅇ, IV). ALÉM DISSO, A LIVRE CONCORRÊNCIA E A BUSCA DO PLENO EMPREGO SÃO AXIOMAS DA ORDEM ECONÔMICA QUE DEVEM SER PRESERVADOS PELO ESTADO DE MODO A ASSEGURAR A TODOS EXISTÊNCIA DIGNA, CONFORME OS DITAMES DE JUSTIÇA SOCIAL. EXEGESE QUE SE EXTRAI DOS ARTIGOS 170, CAPUT E 170, INCISOS IV E VIII, TODOS DA CRFB. A ATIVIDADE DE POLÍCIA ADMINISTRATIVA DO ESTADO SE PREORDENA APENAS A RESTRINGIR O EXERCÍCIO DOS 
DIREITOS INDIVIDUAIS, JAMAIS SUPRIMI-LOS, O QUE TORNA ILEGAL A APLICAÇÃO DAS PENALIDADE CONTIDAS NO DECRETO № 40.518/15 EM RELAÇÃO AO IMPETRANTE, POR CERCEAR A LIBERDADE DE OFÍCIO OU PROFISSÃO CONSAGRADA NO ART. 5, XIII, DA CRFB. PRECEDENTES. A ISENÇÃO PREVISTA NO ART. 17, IX, DA LEI 3.350/90 REFERE-SE TÃOSOMENTE ÀS CUSTAS, NÃO ENGLOBANDO A TAXA JUDICIÁRIA. EXEGESE DO ART. 115 DO CTE E APLICAÇÃO AO CASO DO ENUNCIADO ADMINISTRATIVO № 42 DO FETJ. PRECEDENTES DESTA CORTE. RECURSO CONHECIDO E DESPROVIDO. SEM OS HONORÁRIOS PREVISTOS NO ART. 85, §11, DO NCPC, TENDO EM VISTA A ORIENTAÇÃO QUE EMERGE DO ENUNCIADO ADMINISTRATIVO № 07 DO STJ. UNÂNIME.

Nestes termos acredita-se que a iniciativa da startup Uber possui respaldo constitucional, primeiramente, por não existir vedação constitucional aos serviços que se pretendem prestar, bem como, porque no Brasil são assegurados às empresas os princípios da livre iniciativa e da livre concorrência.

\section{A política nacional de mobilidade urbana e os serviços de transporte público e privado de passageiros}

Superada a análise constitucional, concluindo-se pela viabilidade constitucional da regulamentação da prestação de serviços de transporte individual de passageiros, cumpre analisar a Lei 12.587 de 2012, a qual institui as diretrizes da Política Nacional de Mobilidade Urbana, e estabelece conceitos relevantes para o presente estudo.

A Lei 12.587 de 2012 em seu art. 1ㅇ define que a Política Nacional de Mobilidade Urbana é instrumento da política de desenvolvimento urbano, elaborada com fulcro nos arts. 21, XX e 182, ambos da Constituição, tendo por objetivo integrar os diferentes modos de transporte e prover a melhoria da acessibilidade e mobilidade das pessoas.

Extrai-se do art. 3ำ, §2으 da Lei 12.587 de $2012^{9}$, que a classificação dos serviços de transporte urbano pode ser distinguida por três fatores, quais sejam: o objeto; a característica

\footnotetext{
${ }^{9}$ Art. 3o O Sistema Nacional de Mobilidade Urbana é o conjunto organizado e coordenado dos modos de transporte, de serviços e de infraestruturas que garante os deslocamentos de pessoas e cargas no território do Município.

$\S 1$ 으o modos de transporte urbano:

I - motorizados; e

II - não motorizados.

$\S 2$ 2- Os serviços de transporte urbano são classificados:

I - quanto ao objeto:

a) de passageiros;

b) de cargas;

II - quanto à característica do serviço:

a) coletivo;

b) individual;
} 
do serviço e a natureza do serviço. Em relação ao objeto podem ser classificados entre transporte de passageiros ou de cargas. Quanto à característica do serviço pode ser transporte coletivo ou individual. Por fim, quanto à natureza, pode ser público ou privado.

Esta classificação é essencial para resolver parte da controvérsia existente entre taxistas e a Uber, pois, como foi mencionado no primeiro capítulo, os taxistas sustentam que eles possuem exclusividade para realizar o "transporte público individual" de passageiros, nos termos do art. 2o da Lei 12.468 de 2011.

Inicialmente, cumpre esclarecer que não há controvérsias relacionadas ao objeto dos serviços prestados pelos motoristas da Uber, uma vez que se trata de serviço de transporte de passageiros; bem como, que inexistem discussões acerca da característica do serviço, que se incorre no serviço de transporte individual de passageiros, ainda que seja mais de um passageiro, pois o transporte decorre de viagens individualizadas.

Assim, resta esclarecer o que é transporte público individual de passageiros e verificar se os motoristas ligados à startup a Uber prestam este tipo de serviços. Caso os motoristas da Uber prestem estes serviços, os mesmos estarão realizando ilegalmente serviços exclusivos de taxistas, e em caso contrário, deve-se prosseguir no exame da matéria para verificar o tipo de serviço prestado.

A controvérsia estabelecida está ligada à natureza do serviço, discutindo-se se este serviço é público ou privado. Nestes termos, o art. 4으, da Lei 12.587 de 2012, define o transporte público individual, e não define o que é o transporte privado individual, embora esclareça o conteúdo do transporte motorizado privado, nos dois incisos a seguir:

Art. 4o Para os fins desta Lei, considera-se:

(...)

VIII - transporte público individual: serviço remunerado de transporte de passageiros aberto ao público, por intermédio de veículos de aluguel, para a realização de viagens individualizadas;

$(\ldots)$

$X$ - transporte motorizado privado: meio motorizado de transporte de passageiros utilizado para a realização de viagens individualizadas por intermédio de veículos particulares;

III - quanto à natureza do serviço:

a) público;

b) privado. 
Para se caracterizar um transporte público individual, portanto, é necessário que o serviço contenha quatro requisitos: a) seja um serviço remunerado; b) seja aberto ao público; c) seja realizado por veículos de aluguel ${ }^{10}$; e d) sejam realizadas viagens individualizadas.

No caso dos motoristas da Uber, denota-se que estes não realizam serviços de transporte público individual por dois motivos: primeiro porque não está aberto a todo o público, pois somente podem fazer uso deste serviço quem possuir o aplicativo e, além disso, o motorista pode se recursar a aceitar a corrida, diferente do taxista, que não possui essa liberdade; e o segundo motivo decorre do fato do veículo utilizado pelo motorista da Uber se tratar de veículo particular, e não, veículo de aluguel (OLMOS e FAVERA, 2016, p. 436-437).

Caminhando pela mesma linha de raciocínio, Daniel Sarmento $(2015$, p. 25) reforça que o art. 4ㅇda Lei no 12.587 de 2012 aludiu ao transporte público individual de passageiros (inciso VIII), mas não formulou conceito sobre a modalidade privada. Contudo, esclarece que isso não significa que o legislador deixou de reconhecer essa última modalidade, justificando seu entendimento a partir da interpretação do art. 4ํ, caput, o qual estabelece definições "para os fins" da aplicação da Lei no 12.587/2012, de tal modo que o legislador considerou desnecessário definir o primeiro.

Seguindo em seu raciocínio, Sarmento $(2015$, p. 26) posiciona-se no sentido de que o transporte público individual de passageiros é atividade privativa dos taxistas, conforme previsão contida no art. 2o, da Lei 12.468 de 2011, afirmando que os motoristas parceiros da Uber exercem atividades de transporte privado de passageiros, o qual não foi vedado pelo legislador que elaborou as Leis 12.468 e 12.587, como se observa adiante:

Contudo, não se concedeu aos taxistas o monopólio no exercício de toda a atividade de transporte individual de passageiros - que compreende as modalidades pública e privada. O transporte individual privado de passageiros, previsto na Lei $\mathrm{n} 012.587$ - atividade desempenhada pelos motoristas parceiros da UBER - não foi, nem poderia ter sido, retirado pelo legislador do âmbito da livre iniciativa e livre concorrência.

\footnotetext{
${ }^{10}$ Com fulcro no art. 96, inciso III, do Código de Trânsito Brasileiro, os veículos podem ser classificados, quanto à categoria, como: "a) oficial; b) de representação diplomática, de repartições consulares de carreira ou organismos internacionais acreditados junto ao Governo brasileiro; c) particular; d) de aluguel; e) de aprendizagem." Dentre essa classificação, nos termos do art. 135, do Código de Trânsito Brasileiro, os táxis, na condição de veículos de transporte individual de passageiros, devem ser registrados como veículos de aluguel, sendo que para o registro, o licenciamento e o respectivo emplacamento, deverão estar devidamente autorizados pelo poder público concedente. A partir desta autorização será possível fazer o emplacamento adequado dos táxis, que fazem uso da placa de cor vermelha, ao contrário dos veículos usados por motoristas do Uber, os quais são registrados como particulares e têm placa cinza.
} 
Já, Canotilho (2015, p. 14-15), ao desenvolver seu parecer acerca das atividades prestadas pela Uber, vai além do que foi mencionado acima, e afirma que nem sequer os serviços prestados por taxistas são serviços públicos. Formaliza tal entendimento com fulcro nos arts. 12 e 12-A da Lei 12.587 de 2012, com redação dada pela Lei 12.865 de 2013, afirmando que podem ser extraídas duas conclusões da alteração realizada pela Lei 12.865 de 2013, quais sejam: a) a eliminação legal da qualificação do transporte de passageiros como atividade econômica pública, e por consequência, por se tratar de serviços, estes deixam de se caracterizar como serviços públicos; e b) a revogação da anterior permissão (prevista no dispositivo revogado da Lei 12.587 de 2012) sendo substituída pelo "direito à exploração de serviços de táxi", de tal forma que todos os serviços de transporte individual de passageiros consistem em uma atividade econômica de mercado, e portanto, em uma atividade econômica privada.

Assim, Canotilho entende, na forma do art. 12 da Lei 12.587 de 2012, que a atividade prestada por taxistas consiste em uma "actividade econômica privada de utilidade pública, isto é, uma actividade econômica privada de interesse público (e não de serviço público)." E a partir desta premissa, conclui Canotilho (2015, p. 19): “o próprio regime legal, incluindo o seu modo literal, não é, nem pretende ser excludente, no sentido de que veda o acesso à actividade econômica privada de transporte individual de passageiros a todos e a qualquer cidadão que queira exercê-la."

Neste mesmo sentido, manifestou o Tribunal de Justiça do Distrito federal e Territórios, no Agravo de Instrumento no 2015.00.2.020284-4, julgado pela 4ạ Turma Cível em 30 de setembro de 2015, conforme se observa na ementa a seguir:

AGRAVO DE INSTRUMENTO - SERVIÇO DE TRANPORTE INDIVIDUAL DE PASSAGEIROS - UBER - REGULARIDADE DO SERVIÇO PRESTADO FALTA DE VEROSSIMILHANÇA NAS ALEGAÇÕES DO AGRAVANTE RISCO DE DANO IRREPARÁVEL OU DE DIFÍCIL REPARAÇÃO NÃO CONFIGURADOS.

1. O serviço prestado pelo Uber configura-se como transporte de passageiros individual privado, não se confundindo com o serviço prestado pelos taxistas que se configura como um transporte de passageiros individual público, nos termos da Lei n. 12.468/2011.

2. Não há verossimilhança nas alegações do agravante que pretende a suspensão do aplicativo Uber, tendo em vista a diferença da natureza dos serviços prestados.

3. A manutenção do serviço prestado pelo Uber não gera risco de dano irreparável ou de difícil reparação aos taxistas, tendo em vista a grande demanda de serviço de transporte individual não atendida diante da defasagem da frota de táxis. 
4. Negou-se provimento ao agravo de instrumento.

É importante ressaltar que um parecer sobre o tema também foi formulado por Eros Roberto Grau (2015, p. 04-06), o qual entende que o serviço de transporte individual remunerado de passageiros consiste em serviço público, sendo que esta atividade só poderá ser exercida por um profissional taxista, nos termos da Lei 12.468 de 2011, esclarecendo-se o entendimento do autor no trecho a seguir:

05. Daí o equívoco no qual incidem juristas de renome - inclusive de além-mar - juristas que, em pareceres cujas cópias me vieram com a consulta, tomam alhos por bugalhos. Fazem-no ignorando que, no Brasil, o transporte público individual de passageiros consubstancia serviço público.

Mais ainda, é inteiramente equivocada a afirmação de que a Lei 12.468/2011 regulamente exclusivamente a profissão de taxista, não se aplicando a motoristas que pratiquem o transporte individual remunerado de passageiros por conta de contratos de transporte privado individual.

Pois essa afirmação decorre da suposição de que no transporte público individual remunerado de passageiros impera a autonomia da vontade de qualquer motorista. Suposição de que qualquer motorista, ainda que não taxista, teria o direito de aceitar e firmar contratos com o consumidor de seus serviços, de acordo com sua conveniência. Suposição a que corresponde, elas por elas, a de que seja permitido, no Brasil, o exercício da medicina por qualquer do povo, ainda que não tenha obtido o diploma de médico e inscrição no seu órgão de classe!

Diante dos argumentos citados pelos parecerista mencionados, e apesar das dubiedades encontradas, em especial pela confusa alteração realizada na Lei 12.587 de 2012, acredita-se que a hermenêutica constitucional, aliada à interpretação das leis referidas conduz à conclusão de que o entendimento exposto por Daniel Sarmento é o mais adequado a ser adotado. Este entendimento também foi o adotado no parecer realizado pelo IBAM (2015). Assim, para o presente estudo, entende-se que os táxis prestam serviços públicos de transporte individual de passageiros, enquanto os motoristas vinculados à Uber prestam serviços privados de transporte individual de passageiros.

Este entendimento é reforçado pelo conteúdo a ser exposto no próximo item, em que se observa que o Estado confere uma série de prerrogativas para os taxistas, características típicas oferecidas a particulares que prestam serviços púbicos.

\section{A exclusividade e as prerrogativas dos taxistas em relação ao transporte público individual de passageiros}

É possível observar que os taxistas recebem algumas prerrogativas para o exercício da sua profissão, fato que não se estende aos motoristas da Uber. Desta forma, é pertinente 
observar quais são estas vantagens oferecidas pelo Poder Público, verificando, em momento posterior, se há alguma forma de contraprestação oferecida à sociedade.

Inicialmente é importante destacar que taxistas possuem isenções do pagamento de alguns impostos, como o IOF, O IPI, O ICMS e o IPVA, cujos fundamentos legais são destacados a seguir: a) IPI, cuja isenção decorre da Lei 8.989 de 1995; b) IOF, sendo a isenção concedida nas operações financeiras para a aquisição de automóveis, nos termos do art. 72 da Lei 8.383 de 1991; c) no Estado de São Paulo é possível observar a isenção de ICMS, nos termos do art. 88, do Anexo I, do Regulamento do Imposto sobre Circulação de Mercadorias e sobre Prestações de Serviços e da Portaria CAT 68 de 2001 e d) no Estado de São Paulo observa-se que há isenção do IPVA nos termos do art. 13, IV, da Lei Estadual 13.296 de 2008.

Outra prerrogativa concedida aos taxistas consiste na criação de pontos de táxi, em que aqueles poderão aguardar chamadas de seus clientes ou recebê-los em seus respectivos pontos, sem haver necessidade de ficar rodando a cidade em busca de clientes.

Em alguns municípios existe a denominada taxa de retorno, como se observa no Município de São Paulo, em que o art. 1ำ, §1ํㅡ, I, do Decreto 52.066 de 2010 estabelece o "adicional de viagens metropolitanas: 50\% (cinquenta por cento) no valor da corrida, a ser cobrado no final do percurso, sobre o valor total marcado no taxímetro, se não houver retorno do passageiro".

Outra prerrogativa que se identifica na cidade de São Paulo consiste na possibilidade conferida aos taxistas de usar os corredores exclusivos de ônibus do sistema de transporte público, como se observa na Portaria no 83 de 2016.

Também é importante ressaltar, por outro lado, que os taxistas possuem alguns deveres que os motoristas da startup Uber não possuem, como o pagamento de taxa ao governo, sendo que um taxista deve pagar uma taxa ao Município e a licença anual. Ademais, os taxistas precisam fazer, a cada cinco anos um exame médico e psicotécnico no Detran.

O que se denota neste capítulo é que embora os taxistas possuam alguns deveres e prerrogativas que os motoristas da Uber não possuem, pode-se observar de um modo geral que as prerrogativas oferecem, como regra, mais vantagens do que desvantagens aos taxistas, comparando-se com os ônus suportados pelos motoristas da Uber.

Destaca-se que um dos argumentos utilizados pelos taxistas com o intuito de vedar a atividade das startups voltadas para o transporte privado individual de passageiros consiste na arguição de que estes não realizam pagamentos de impostos, fundamento que não se 
estabelece, e bem pelo contrário, é possível observar o contrário, pois são os taxistas que acabam recebendo isenções não previstas para os motoristas da Uber.

Diante deste contexto, pode-se dizer, de certa forma, que a contribuição social de ambos os serviços para a sociedade é bem limitada, sendo que a contribuição em relação ao pagamento de impostos em relação aos taxistas pode ser bem menor do que a contribuição dos motoristas da Uber.

Por tais motivos reputa-se relevante prosseguir no estudo e verificar de que forma o transporte individual de passageiros pode influenciar a acessibilidade à população, tudo sob uma perspectiva democrática e cidadã.

\section{A ACESSIBILIDADE NO ESTADO DEMOCRÁTICO DE DIREITO}

O Estado Democrático de Direito decorre de uma evolução do conceito de Estado. A concepção de Estado na idade moderna abrange inicialmente o conceito de Estado absolutista, o qual evolui para o Estado Liberal a partir da revolução Francesa, evoluindo seguidamente para o Estado Social e, por fim, para o Estado Democrático de Direito.

O Estado Democrático de Direito diferencia-se dos demais, em especial ao referendar valores, que se agregam ao seu conteúdo, influenciando a sociedade para a promoção de valores como a dignidade da pessoa humana e outros princípios, para que esta se torne mais igualitária para todos, sendo relevante analisar alguns destes princípios e de que forma estes atuam no direito.

\section{Estado democrático de direito}

O papel do Estado Democrático de Direito está especialmente relacionado à promoção dos direitos do homem, com destaque às garantias relacionadas com a dignidade da pessoa humana (LIBERATI, 2013, p. 74). Reforçando esta premissa, Sarlet (2015, p. 112-113) esclarece que "é o Estado que existe em função da pessoa humana, e não o contrário, já que o homem constitui a finalidade precípua, e não meio da atividade estatal."

A promoção do Estado Democrático é realizada a partir da proteção dos direitos do homem, acrescida da proteção dos direitos sociais, como pretende o welfare state, tudo em adequação com uma interpretação diferenciada, inclusiva e democrática, voltada para valores como a dignidade da pessoa humana e outros princípios constitucionais, os quais exigem uma interpretação diferenciada do direito, e com base em valores, torna-se imprescindível a 
realização de interpretações construtivistas, voltadas para a discussão do papel da Constituição (XIMENES, s/a, p. 1-2).

Dentro deste contexto, é importante esclarecer que se pretende realizar o presente estudo a partir da questão da igualdade, explicada por Streck e Morais (2008, p. 104) como um conteúdo próprio, garantido por intermédio do asseguramento jurídico de condições mínimas de vida ao cidadão e à comunidade, exercendo o Estado um papel transformador do status quo, para reestruturar a sociedade, agregando o elemento da democracia ao direito.

Para que haja igualdade é relevante que exista equidade de possibilidades para os cidadãos. Uma sociedade composta por diversos seres humanos possui desigualdades, pois as pessoas, em razão da essência que lhes caracterizam, são diferentes e assim, possuem desejos e necessidades distintas. Neste contexto, é importante destacar o conceito de igualdade elaborado por John Rawls, o qual desenvolve sua teoria da justiça a partir da ideia de oferecer igualdade de oportunidades às pessoas, como se passa a explicar.

\section{A igualdade equitativa de oportunidades para John Rawls}

Inicialmente, é importante esclarecer que Rawls, ao contrário de Kelsen e Perelman, não desenvolve sua teoria de justiça através de um critério específico e supostamente eficaz para avaliar uma norma de justiça isolada. O que Rawls propõe é o exame de uma estrutura básica para uma determinada sociedade (GODOI, 1999, p. 42).

Assim Rawls elabora "Uma teoria da justiça" com o intuito de criar uma alternativa viável às doutrinas do intuicionismo e da postura utilitarista. A partir deste viés, a teoria de Rawls, publicada em 1973, passou a repercutir mundialmente, gerando um marco na filosofia política (GARGARELLA, 2008, p. 02).

Rawls adota uma postura contratualista, passando a analisar a sociedade como uma associação relativamente autossuficiente de indivíduos, que em seu convívio reconhecem regras de conduta obrigatórias, as quais caracterizam um sistema de cooperação social. Os indivíduos reconhecem que este sistema é dirigido para a concepção do bem comum das pessoas. Neste contexto, em determinadas situações, há identidade de interesses entre os indivíduos, pois nestas circunstâncias, todos podem ter uma vida melhor do que teriam isoladamente; e em outras situações há interesses de conflitos, pois as pessoas podem discordar com relação aos modos de repartição dos benefícios e dos ônus gerados pela existência da vida em sociedade (GODOI, 1999, p. 42). 
Desta maneira, Rawls formulou uma teoria que sustenta a necessidade de um critério de justiça com o intuito de estabelecer uma "sociedade bem ordenada". Rawls acredita que a sociedade é assentada nas vantagens da cooperação, conduzida por razões individualistas de associação política, o que implica, invariavelmente, em conflitos de interesses, que serão transpostos em suas Constituições.

Para sanar estes conflitos, os princípios de Justiça apresentados por Rawls seriam o fundamento para a neutralização dos confrontos, uma vez que esses princípios seriam de consenso entre toda a população. Os conteúdos desses princípios são, conforme Luzia Marques da Silva Cabral Pinto (1994, p. 106): o princípio da liberdade igual, que consiste no direito igual ao mais amplo sistema de liberdades básicas e no princípio da diferença, que consiste na dissolução das desigualdades sociais e econômicas estruturadas de maneira que contribuam de melhor forma para os menos favorecidos.

É importante analisar os princípios especificamente formulados por Rawls (2016, p. 376) para melhor compreender a sua teoria, como se observa a seguir:

\section{Primeiro princípio}

Cada pessoa deve ter um direito igual ao mais abrangente sistema total de liberdades básicas iguais que seja compatível com um sistema similar de liberdades para todos.

Segundo princípio

As desigualdades econômicas e sociais devem ser dispostas de modo a que tanto:

(a) se estabeleçam para o máximo benefício possível dos menos favorecidos que seja compatível com as restrições do princípio de poupança justa, como

(b) estejam vinculadas a cargos e posições abertos a todos em condições de igualdade equitativa de oportunidades.

Ou seja, o que Rawls propõe, é que todos os valores sociais (liberdades básicas, oportunidades, renda, riqueza, bases sociais da auto-estima individual) devem ser distribuídos igualitariamente, a não ser que uma distribuição desigual de um ou de todos estes valores traga vantagens para todos (GODOI, 1999, p. 45).

Assim, um elemento importante da teoria de Rawls para o presente trabalho diz respeito ao princípio liberal de igualdade equitativa de oportunidades, que se trata da segunda parte do segundo princípio (hipótese 'b') (RAWLS, 2016, p. 101).

Ao desenvolver este tema, Rawls aponta que a segunda parte do segundo princípio suscita a ideia de que as parcelas distributivas incorrem em uma questão de justiça procedimental pura, para que a distribuição de bens e riquezas não seja feita de modo meramente formal, de tal forma que o princípio determina que se assegurem iguais 
perspectivas de cultura e realização para todos, independentemente de sua classe social, podendo este princípio atuar como um limitador do desenvolvimento do mercado capitalista, pois as contingências sociais e naturais podem retirar a justiça do sistema social (GODOI, 1999, p. 53).

E é a partir deste contexto, em especial desta segunda parte do segundo princípio da teoria de justiça de Rawls, com o foco voltado para a igualdade material entre os sujeitos, que se possibilita eventual limitação do mercado capitalista. Assim, a partir do exame de um direcionamento do mercado capitalista é que se pretende analisar as exclusões sociais que podem decorrer do uso do Uber, do táxi, ou de serviços assemelhados.

\section{A acessibilidade urbana como fator de exclusão social}

Para que se concretize o objetivo constitucional de tornar a sociedade mais livre, justa e solidária (art. 3ํ, I, da Constituição) é importante evitar que ocorram exclusões decorrentes de desigualdades sociais, de tal forma que o presente item deste estudo está voltado para demonstrar de que forma a (in)acessibilidade urbana pode ser considerada um fator de exclusão social.

A noção de exclusão social ganhou visibilidade teórica e empírica nas últimas décadas do século passado, a partir das reflexões de René Lenoir, na obra de 1974: "Os excluídos: um em cada dez franceses (Les exclus: um français sur dix)".

Observa-se, portanto, que o conceito de exclusão social é um conceito relativamente moderno, o qual não possui um consenso acerca de seu conteúdo. Ademais, pobreza e exclusão social são, muitas vezes, vistas conjuntamente, reforçando-se mutuamente, havendo reiteradas confusões entre os seus conceitos (SANTOS FILHO, 2015, p. 115).

Neste sentido observa-se a contextualização feita por Sawaya (2001, p. 07):

Exclusão é tema da atualidade, usado hegemonicamente nas diferentes áreas do conhecimento, mas pouco preciso e dúbio do ponto de vista ideológico. Conceito que permite usos retóricos de diferentes qualidades, desde a concepção de desigualdade como resultante de deficiência ou inadaptação individual, falta de qualquer coisa, um sinônimo do sufixo sem (less), até a de injustiça e exploração social.

Seguindo esta mesma linha de entendimento e apartando o conceito de exclusão social da pobreza, observam os apontamentos de Trannin, Costa e Pinto (2015, p. 119):

Comumente a pobreza é vinculada à ideia de exclusão social. Mas é preciso salientar que nem sempre a exclusão social está vinculada à pobreza, uma vez que a exclusão pode dar-se em decorrência de diversos fatores, como desemprego, situações precárias de trabalho, minorias 
étnicas, idade, religião, deficiência física ou mental, em suma, há muitas formas de exclusão social que sempre consistirá em um processo no qual o indivíduo, progressivamente, é afastado da sociedade.

Diversos podem ser os motivos que geram as desigualdades, e estas podem ser agravadas pela manutenção de condições inadequadas de acesso aos meios e equipamentos de consumo coletivo, dentre os quais se destaca o sistema de transportes, o qual possui relevância para a ampliação ou na mitigação do processo de exclusão social, assim como o oferecimento de uma vida digna aos cidadãos (CARDOSO, 2007, p. 17).

Observa-se que, a partir da leitura da obra de René Lenoir, Mariangela Belfiore Wanderley (2001, p. 17) compreende que são causas da exclusão social "o rápido e desordenado processo de urbanização, a inadaptação e uniformização do sistema escolar, o desenraizamento causado pela mobilidade profissional, as desigualdades de renda e de acesso aos serviços."

Nestes termos, pode-se compreender que um dos fatores que envolvem a exclusão social está diretamente relacionada à acessibilidade urbana. E neste ponto lúcido é o esclarecimento realizado por Leandro Cardoso (2007, p. 19) ao citar S. R. Jones:

JONES (1981) relaciona acessibilidade com a oportunidade que um indivíduo possui para participar de uma atividade em um dado local, sendo tal potencialidade disponibilizada pelo sistema de transporte e pelo uso do solo, o que permitiria que diferentes tipos de pessoas desenvolvessem suas atividades. (...) O primeiro irá depender da performance do sistema de transporte, revelada pela capacidade deste interligar locais espacialmente distintos.

Seguindo em sua análise, Leandro Cardoso (2007, p. 21) acrescenta que a acessibilidade pode ser observada como um "indice locacional de atividades" as quais representam maior ou menor acessibilidade para alcançar oportunidades oferecidas, de acordo com os meios de transporte, a localização e as atividades disponíveis.

O que o Leandro Cardoso (2007, p. 23) constata (sendo este um relevante aspecto para o presente trabalho), é que em um contexto de amplas carências sociais, típicas dos países periféricos, a insuficiência de modos alternativos de transporte que independam de financiamento, além de problemas relacionados à limitada integração física e tarifária entre os transportes coletivos (responsáveis pela maioria dos deslocamentos intra-urbanos), resultam num processo de discriminação geográfica e, portanto, de exclusão social, pois os indivíduos de menos posses, ou que moram em locais distantes, possuem dificuldades para alcançar oportunidades de trabalho, estudo, consumo e lazer. 
Ou seja, o que se observa é que a acessibilidade se torna “(...) parte integrante e fundamental da dinâmica e do funcionamento das cidades, e passa a ser um elemento que contribui para a qualidade de vida urbana, na medida em que facilita o acesso da população aos serviços e equipamentos urbanos, além de viabilizar sua aproximação com as atividades econômicas." (CARDOSO, 2007, p. 31).

Neste contexto, muitas vezes é possível observar que algumas políticas públicas, optam por privilegiar a eficiência econômica em detrimento da equidade, o que permite um processo de exclusão social, que se acentua entre centro e periferia. Ademais, este processo de exclusão pode englobar não somente aqueles que moram em pontos distantes dos centros urbanos, mas também aqueles que possuem necessidades especiais, pois o acesso até o transporte público coletivo pode ser inviável.

O que se observa, portanto, é que "a adoção de práticas e estratégias alternativas de (re)dimensionamento das relações entre uso do solo e transporte, poderia contribuir para minorar processos de exclusão social e para um desenvolvimento mais equilibrado e sustentável do espaço urbano." (CARDOSO, 2007, p. 35)

Dentro deste contexto, em que se pretende a construção de um Estado Democrático de Direito, é realizado o exame dos novos aplicativos voltados para o transporte individual de passageiros, com especial enfoque para que seja garantida ampla acessibilidade, oferecendo maior igualdade de oportunidades àqueles que desejam fazer usos destes serviços.

\section{A REGULAMENTAÇÃO DOS SERVIÇOS DE TRANSPORTE PRIVADO INDIVIDUAL DE PASSAGEIROS}

No segundo capítulo foi possível estabelecer duas relevantes conclusões: a primeira, no sentido de que a Constituição não veda o transporte privado individual de passageiros, bem pelo contrário, estimula este tipo de atividade por intermédio dos princípios da livre iniciativa e da livre concorrência; e a segunda, no sentido de que a Lei 12.468 de 2011 não veda o exercício do transporte privado individual de passageiros.

Neste ponto é importante ressaltar a premissa realizada por Daniel Sarmento (2015, p.22), o qual aponta que: “(...) a ausência de regulamentação de determinada atividade econômica em sentido estrito não importa em vedação ao seu exercício, mas em possibilidade de atuação do particular. É o que decorre do princípio da livre empresa, consagrado no art. 170, 
parágrafo único, da Constituição". Ou seja, na ausência de regulamentação, resta permitida a atuação pela iniciativa privada.

A partir das conclusões obtidas no capítulo segundo, no capítulo terceiro foi analisado o conteúdo de um Estado Democrático e igualitário, responsável por tornar a mobilidade urbana acessível para toda a população, evitando-se qualquer tipo de exclusão social.

E após o reconhecimento destas premissas, neste capítulo, pretende-se analisar de que forma o ingresso regular do serviço de transporte privado individual de passageiros pode ser bom para a população e qual seria a melhor forma de regulamentar estas atividades.

\section{A competitividade no mercado de transporte de passageiros e os reflexos para os consumidores}

Gomide (2006, p. 247) faz relevante alerta ${ }^{11}$ apontando que, no quadro de delegação dos serviços à iniciativa privada, é comum a inexistência de mecanismos competitividade, sendo que a situação das delegações dos serviços à iniciativa privada acaba sendo agravada, pois os serviços delegados, via de regra, nem sequer estão submetidos a critérios de eficiência, ao contrário do que estabelece a legislação de concessões de serviços públicos em vigor. Estas circunstâncias podem gerar impactos negativos nos preços e na qualidade dos serviços, atuando como um fator de aumento da ineficiência do transporte público.

Neste sentido Daniel Sarmento $(2015$, p. 09) esclarece que a livre inciativa é benéfica para a sociedade, coadunando-se à ideia de competitividade e melhora da eficiência, nos seguintes termos:

Na dimensão coletiva, a premissa é de que a sociedade tende a ser mais próspera quando assegura a liberdade aos agentes econômicos, do que quando o Estado se apropria dos meios de produção ou planifica completamente a economia. A garantia da livre iniciativa estimula o empreendedorismo, gerando maior riqueza social. Não por outra razão, Cass Sunstein, jurista insuspeito de simpatias libertárias, afirmou que os mercados livres "são motores de produtividade econômica". Ademais, o funcionamento regular de um mercado competitivo tende a ser instrumento mais eficiente para a captação e satisfação das necessidades e preferências de um universo amplo e plural de pessoas do que a atuação de qualquer autoridade pública. Por isso, o bem-estar coletivo é promovido quando as instituições asseguram a livre iniciativa e preservam as "regras do jogo" em que ela se desenvolve de modo saudável - o que não exclui, é claro, a intervenção estatal na economia

\footnotetext{
11 Observa-se que a referência de Gomide refere-se ao transporte coletivo de passageiros, mas esta análise também é válida se aplicável ao transporte individual de passageiros.
} 
voltada à promoção de outros objetivos legítimos que o mercado não atende bem, como a distribuição de riqueza.

Considerando ainda, que a Política Nacional de Mobilidade Urbana, nos termos do art. 5으, IV e IX, da Lei 12.587/2012, está fundada nos princípios da eficiência, eficácia e efetividade na prestação de serviços de transporte urbano e de circulação urbana, é relevante fazer uma reflexão acerca da regulamentação e abertura dos serviços de transporte privado individual de passageiros à população em geral.

Nestes termos, o CADE realizou alguns estudos acerca da entrada do Uber no mercado, destacando-se dois estudos para o presente trabalho (2015a e 2015b), os quais apontam para o fato de que a regulamentação do mercado de transporte privado individual de passageiros é benéfica para a sociedade, em especial por se permitir a competitividade, nos seguintes termos:

Finalmente, é necessário discutir a regulação do mercado de transporte individual de passageiros, visto que não há elementos econômicos que justifiquem a proibição de novos prestadores de serviços de transporte individual. Para além disso, elementos econômicos sugerem que, sob uma ótica concorrencial e do consumidor, a atuação de novos agentes tende a ser positiva (CADE, 2015a, p. 48).

Isto decorre do fato de que ao longo dos estudos realizados pelo CADE (2015a, p. 45) foi possível visualizar que as soluções tecnológicas propiciadas pelos aplicativos de smartphones permitem que vários dos problemas que justificaram e serviram historicamente como argumentos favoráveis para a regulação de táxis sejam superados, tornando a auto-regulação do mercado decorrente das startups (como a Uber; cabify; willgo; fleety; televo; T81; entre outras) uma fonte apta a garantir a credibilidade de bons serviços e preços à população em geral. Tais fatos despertam na sociedade a reflexão sobre a necessidade de ser mantida a regulação para o mercado do transporte individual de passageiros.

Esta competitividade, portanto, demonstra-se benéfica para o consumidor, podendo-se destacar o estudo realizado pela Technology Policy Institute, coordenado por Scott Wallsten (2015, p. 19), no qual se denota que os efeitos da competitividade entre Uber e taxi nas cidades de Nova lorque e Chicago fizeram com que os taxis tenham aumentado a qualidade dos serviços e reduzido os preços praticados.

Por tais motivos, demonstra-se a pertinência da regulamentação dos serviços de transporte privado individual de passageiros, pois podem ser gerados benefícios para os consumidores e para a sociedade em geral, em especial se for realizada uma regulamentação sob uma perspectiva democrática e inclusiva. 


\section{A competência para a regulamentação dos serviços de transporte privado individual de passageiros}

Para regulamentar os serviços de transporte privado individual de passageiros, seja no sentido de regularizar a atividade, seja para proibi-la, é essencial verificar a competência para cumprir tal mister.

Neste sentido, é importante analisar a Constituição Federal, com especial destaque para o art. 22, IX, o qual prevê que é competência privativa da União legislar sobre as diretrizes da política nacional de transportes. Ademais, o art. 21, XX, da Constituição prevê a competência da União para instituir diretrizes para o desenvolvimento do transporte urbano.

Denota-se, portanto, que a Constituição é clara ao assegurar à União a competência privativa para regulamentar a política nacional de transportes e por consequência, o transporte privado individual de passageiros.

Seguindo este entendimento Daniel Sarmento (2015, p. 36) esclarece que a competência privativa da União afasta a competência residual dos Estados, do Distrito Federal e dos Municípios, previstas no art. 30, I e II, nos seguintes termos:

As competências legislativas privativas da União - seja mais uma vez escusada a redundância -, exatamente porque privativas, excluem a de todos os demais entes federativos para tratamento das mesmas matérias, ressalvada apenas a possibilidade de delegação aos Estados, por lei complementar, da faculdade de disciplinarem questões específicas dentre as arroladas no art. 22 da Constituição, nos termos do Parágrafo único do mesmo preceito constitucional. Assim, tais competências privativas afastam as competências não enumeradas atribuídas aos municípios e Distrito Federal78, para "legislar sobre assuntos de interesse local" (art. 30, inciso I, CF), e para "suplementar a legislação federal e estadual, no que coUber" (art. 30, inciso II, CF).

Ademais, no mesmo sentido posiciona-se Canotilho (2015, p. 30):

Estas reservas ou exclusivas, proibições e inibições, de forma primária e inovatória, a legislar sobre matéria - diversa matéria - que é da competência legislativa privativa da União. A inconstitucionalidade orgânica de tais diplomas é, pois, directa e manifesta, por invasão das competências legislativas constitucionalmente reservadas à intervenção prévia e inovatória da União.

Ou seja, o que se observa, com base nos princípios elencados, e com base nas competências definidas na Constituição é que a União possui poder para regulamentar a atividade de transporte privado individual de passageiros, de tal forma que a atuação dos Estados, do Distrito Federal e dos Municípios limita-se à regulamentação dos interesses regionais ou locais, em conformidade com a lei a ser elaborada pela União. 
Assim, o Estado possui poder para intervir na atividade econômica, bem como para normatizá-la ou fomentar ações privadas consideradas socialmente desejáveis. Para exercer esta competência, deve a União atender aos interesses e às limitações impostas pela Constituição, tais como: os princípios da proporcionalidade, da legalidade e da igualdade. Atendidos estes preceitos poderá ser conferida plena liberdade para os particulares atuarem no mercado (SARMENTO, 2015, p. 15).

\section{A regulamentação do transporte privado individual de passageiros em conformidade com uma política de acessibilidade democrática e inclusiva}

É pertinente elucidar a principal pretensão do presente trabalho com as palavras de Daniel Sarmento (2015, p. 07-08), o qual relativiza o princípio da livre iniciativa, apontando que a Constituição permite intervenções estatais na economia para a promoção de objetivos sociais como a igualdade e a justiça social:

É certo que o princípio da livre iniciativa não ostenta caráter absoluto e incondicional na ordem constitucional brasileira. Afinal, a Constituição de 88 está longe de consagrar um modelo econômico libertário, à moda do laissez-faire do século XIX, como se percebe de outros fundamentos, objetivos e princípios também contemplados no seu art. 170 - e.g., "valorização trabalho humano", "existência digna", "justiça social", "função social da propriedade", "defesa do meio ambiente", "redução das desigualdades regionais e sociais". Nossa Constituição legitima a intervenção estatal na economia não apenas para corrigir as chamadas "falhas do mercado", como também para promover outros objetivos fundamentais, como a igualdade substantiva e da justiça social.

A partir deste preceito, observa-se que a União pode estabelecer regras gerais relacionadas ao transporte privado individual de passageiros, devendo atender aos parâmetros constitucionais, podendo, ainda regulamentar serviços com o intuito de proteção de objetivos fundamentais como a igualdade e a justiça social.

Em sentido parelho, é relevante destacar o art. 2oㅡ, da Lei 12.587 de 2015, o qual estabelece os objetivos da Política Nacional de Mobilidade Urbana:

Art. 2‥ A Política Nacional de Mobilidade Urbana tem por objetivo contribuir para o acesso universal à cidade, o fomento e a concretização das condições que contribuam para a efetivação dos princípios, objetivos e diretrizes da política de desenvolvimento urbano, por meio do planejamento e da gestão democrática do Sistema Nacional de Mobilidade Urbana.

É relevante destacar que dentre os objetivos está presente a concretização de condições que contribuam para o acesso universal à cidade, o que consiste em um relevante fator para evitar a exclusão social. 
Seguindo esta mesma linha, o art. 24, IV, da referida Lei prevê que o Plano de Mobilidade Urbana deve contemplar "a acessibilidade para pessoas com deficiência e restrição de mobilidade".

Denota-se, portanto, que para o alcance da acessibilidade por toda a população é importante haver o atendimento daqueles que por razões genéticas ou por fatos da vida possam ter dificuldades de acesso aos serviços prestados.

Assim, seria relevante uma lei que garantisse acessibilidade aos serviços de transporte privado individual de passageiros às pessoas com deficiência ou com mobilidade reduzida, nos termos do art. 1ํ, da Lei 10.098 de 2000, para não gerar exclusão em relação a estes.

Insta salientar que, até mesmo os edifícios privados devem conferir opções de acessibilidade às pessoas com deficiência ou com mobilidade reduzida. Parece muito mais adequado que a prestação de serviços voltados para as pessoas em geral também deva atender a estes parâmetros para não gerar exclusão.

Ressalte-se que esta exclusão pode ser majorada pela diferença tarifária existente entre a Uber e os taxis, pois como restou demonstrado na tabela 1, a tarifa de táxi, em regra é mais cara que a da Uber, de tal forma que exigir das pessoas portadoras de deficiência ou daqueles que possuem dificuldade de locomoção, que façam uso obrigatório dos serviços de táxis seria um ônus adicional, o qual teria o condão de aumentar as condições de desigualdade que estas pessoas enfrentam ao longo de suas vidas.

Sugere-se, a título exemplificativo, que a forma voltada para o atendimento desta demanda seja realizada por intermédio do estabelecimento de um percentual mínimo da frota, ou pelo estabelecimento de um pagamento diferenciado aos motoristas que atenderem esta parte da demanda (pagamento este que pode ser subsidiado por todo o sistema, fazendo com que esse valor diferenciado seja custeado por todos os seus usuários).

Outro grupo social excluído dos serviços prestados pela Uber são as pessoas com deficiência visual. Dois são os motivos que imperam para ocorrer a inacessibilidade: a) o aplicativo depende de alguém que enxergue para ser utilizado e b) não há possibilidade de requisitar especificamente um veículo que possa fazer o transporte de cão-guia.

Desta forma, sugere-se que eventual lei a ser elaborada possa exigir que haja adaptação do dispositivo para solicitação de viagem ou por comando de voz, ou de alguma forma que algum pessoa portadora de deficiência visual possa fazer uso do aplicativo. 
Em relação ao cão-guia, a Lei № 11.126 de 2005 e o Decreto № 5904 de 2006 tratam dos direitos das pessoas portadoras de deficiência visual de ingressar e permanecer em ambientes de uso coletivo acompanhado de cão-guia. Logo no art. 1ํo está previsto que

É assegurado à pessoa com deficiência visual acompanhada de cão-guia o direito de ingressar e de permanecer com o animal em todos os meios de transporte e em estabelecimentos abertos ao público, de uso público e privados de uso coletivo, desde que observadas as condições impostas por esta Lei.

Acredita-se que poderia haver a extensão desta política de acessibilidade para o transporte de pessoas com deficiência visual acompanhados de cães-guia no transporte privado individual de passageiros, ainda que seja somente por parte da frota, para que não gere, assim como nos casos das pessoas com deficiência física, uma exclusão destes.

Nestes termos, seria possível acrescentar ao aplicativo, motoristas que façam o atendimento de transporte de cães-guia e outros animais de estimação, o que viria a atender uma demanda que ainda não é prevista pelas startups. Da mesma forma que foi mencionado para a acessibilidade às pessoas portadoras de deficiência física, a Lei poderia prever que seja estabelecido um percentual mínimo da frota para atender esta demanda, ou pelo estabelecimento de um pagamento diferenciado aos motoristas que realizarem tais atendimentos (pagamento este que pode ser subsidiado por todo o sistema, fazendo com que esse valor diferenciado seja custeado por todos os seus usuários).

Por fim, uma relevante forma de permitir acessibilidade diz respeito à forma de pagamento. Não deve ser admissível a não aceitação do pagamento em dinheiro, por força do contido no art. 39, IX do Código de Defesa do Consumidor (Lei no 8.078 de 1990).

Além de haver previsão legal vedando a negativa de aceitação do pagamento em dinheiro, ainda deve-se destacar que nem todos possuem contas bancárias ou cartões de crédito, sendo um direito do cidadão não fazer uso destes serviços. Ademais, para algumas pessoas cuja renda seja bem limitada, tais serviços podem ensejar em custos que os mesmos não possam despender. Nestes casos, ao se recusar a receber o pagamento em dinheiro, o transporte privado individual de passageiros estará fomentando uma situação de exclusão social.

Por tais motivos, entende-se que é adequado que eventual Lei que venha a regulamentar o transporte privado individual de passageiros inclua a obrigatoriedade de aceitação de pagamento em dinheiro.

Pelo exposto, não há dúvidas de que a lei pode impor limitações ao exercício da atividade empresarial, desde que haja compatibilidade com os objetivos da República e de 
forma proporcional, não restrinjam em demasia a livre iniciativa e a livre concorrência. Ou seja: "Tais normas restritivas devem se voltar à proteção de objetivos legítimos - dentre os quais certamente não figura a defesa corporativa de segmentos econômicos prejudicados pela concorrência." (SARMENTO, 2015, p. 24).

\section{CONCLUSÃO}

Após o presente estudo, foi possível concluir, em um primeiro momento, que os serviços prestados por taxistas e motoristas da Uber possuem diferenças significativas, em especial no que tange à sua natureza, uma vez que os serviços de táxis se constituem em transporte público individual de passageiros, ao contrário dos serviços prestados pela Uber e similares, a qual realiza transporte privado individual de passageiros.

Em razão destas diferenças e da entrada de startups privadas atuando em um mercado que antes era prestado exclusivamente por taxistas, acredita-se que os conflitos existentes tendem a ser mantidos, e eventualmente agravados, sendo que o Estado tem o dever constitucional de atuar para evitar ou, ao menos, reduzir a existência destes conflitos.

Outrossim, acredita-se que a atuação estatal atenderá de forma mais ampla aos interesses públicos se permitir o transporte privado individual de passageiros, ao invés de proibi-lo, pois isto atenderá de melhor forma os critérios pretendidos pela Política Nacional de Mobilidade Urbana.

Para que esta regulamentação seja realizada atendendo aos interesses públicos e em conformidade com o Estado Democrático de Direito, acredita-se que eventual lei deva atender a critérios que promovam igualdade de oportunidades à toda a população, seguindo ideais da teoria da justiça de John Rawls, principalmente com base na equidade de oportunidades, bem como, que atendam a uma diversidade de públicos, evitando a exclusão social de grupos tais como as pessoas portadoras de deficiência física e visual, ou ainda, de pessoas mais pobres que não façam uso de determinados serviços bancários.

Entende-se que a regulamentação que abranja todos estes grupos não afetará o acesso ao mercado, bem como que promoverá igualdade entre os diversos grupos sociais, pois mesmo que a atividade privada seja um pouco onerada para atender tais demandas, ainda será viável a prestação de serviços sem oferecer demasiados encargos à iniciativa privada, o que atende aos princípios constitucionais da proporcionalidade e da igualdade, melhorando a mobilidade 
urbana para todos de uma forma geral e promovendo a justiça social e o Estado Democrático de Direito.

\section{REFERÊNCIAS}

BRASIL. Constituição da República Federativa do Brasil de 1988. Atual. até a Emenda Constitucional no 91 de 2016.2 Disponível em: <https://www.planalto.gov.br/ccivil_03/Constituicao/Constituicao.htm\#art182>. Acesso em 03 de maio de 2017.

Lei no 8.078, de 11 de set. de 1990. Disponível em: <https://www.planalto.gov.br/ccivil_03/Leis/L8078.htm>. Acesso em 03 de maio de 2017.

Lei no 8.383, de 30 de dez. de 1991 . Disponível em: <https://www.planalto.gov.br/ccivil_03/leis/L8383.htm>. Acesso em 03 de maio de 2017.

Lei no 8.989, de 24 de fev. de 1995. Disponível em: <http://www.planalto.gov.br/ccivil_03/leis/L8989.htm>. Acesso em 03 de maio de 2017.

Lei no 10.098, de 19 de dez. de 2000 . Disponível em: <http://www.planalto.gov.br/ccivil_03/leis/L10098.htm>. Acesso em 03 de maio de 2017.

Lei no 11.126, de 27 de jun. de 2005 . Disponível em: <https://www.planalto.gov.br/ccivil_03/_ato2004-2006/2005/lei/l11126.htm>. Acesso em 03 de maio de 2017.

Lei no 12.468, de 26 de ago. de 2011. Disponível em: <http://www.planalto.gov.br/ccivil_03/_Ato2011-2014/2011/Lei/L12468.htm>. Acesso em 03 de maio de 2017.

Lei no 12.587, de 03 de jan. de 2012. Disponível em: <https://www.planalto.gov.br/ccivil_03/_ato2011-2014/2012/lei/l12587.htm>. Acesso em 03 de maio de 2017.

CADE - Conselho Administrativo de Defesa Econômica. DEE - Departamento de Estudos Econômicos. ESTEVES, Luiz Alberto (economista-chefe). O Mercado de Transporte Individual de Passageiros: Regulação, Externalidades e Equilíbrio Urbano. Documentos de Trabalho 001/2015. Brasília, set. de 2015. Disponível em: <http://www.cade.gov.br/acesso-ainformacao/publicacoes-institucionais/dee-publicacoes-anexos/o-mercado-de-transporteindividual-de-passageiros.pdf>. Acesso em 03 de maio de 2017.

CADE - Conselho Administrativo de Defesa Econômica. DEE - Departamento de Estudos Econômicos. ESTEVES, Luiz Alberto (economista-chefe). Rivalidade Após Entrada: O impacto imediato do aplicativo Uber sobre as corridas de táxi porta-a-porta. Documentos de Trabalho 003/2015. Brasília, dez. de 2015. Disponível em: <http://www.cade.gov.br/acesso-ainformacao/publicacoes-institucionais/dee-publicacoes-anexos/rivalidade-apos-entrada-oimpacto-imediato-do-aplicativo-Uber-sobre-as-corridas-de-taxi.pdf>. Acesso em 03 de maio de 2017.

Instituto Brasileiro de Administração Municipal (IBAM). Parecer no 2545/2015. Disponível em: < http://lam.ibam.org.br/parecer_detalhe.asp?idp=20152545>. Acesso em 03 de maio de 2017.

Instituto Nacional de Metrologia, Normalização e Qualidade Industrial - INMETRO. Portaria INMETRO o 120, de 23 de agosto de 1995. Disponível em: <http://www.inmetro.gov.br/rtac/pdf/RTAC000186.pdf>. Acesso em 03 de maio de 2017.

Tribunal Regional do Trabalho da Terceira Região. 9a Turma. Recurso Ordinário no 0011359-34.2016.5.03.0112. Recorrente Uber do Brasil Tecnologia Ltda Recorrido Rodrigo 
Leonardo Silva Ferreira. Relatora Desembargadora Maria Stela Álvares da Silva Campos. 23 de mai. de 2017.

CANCIÁN, Marco Rogério Soranzo. Análise da Percepção dos Usuários quanto ao Serviço da Empresa Uber. 79 f. Monografia (Graduação em Administração), Faculdade de Economia, Administração e Contabilidade, Brasília, 2016.

CANOTILHO, José Joaquim Gomes. Parecer: A atividade econômica privada de transporte individual de passageiros, na sua modalidade privada e o "sistema Uber". Coimbra, 26 de out. de 2015. Disponível em: <http://s.conjur.com.br/dl/parecer-canotilho-Uber.pdf>. Acesso em 03 de maio de 2017.

CARDOSO, Leandro. Transporte Público, Acessibilidade Urbana e Desigualdades Socioespaciais na Região Metropolitana de Belo Horizonte. 232 f. Tese (Doutorado em Geociências), Universidade Federal de Minas Gerais, 2007.

DISTRITO FEDERAL. Tribunal de Justiça do Distrito Federal e Territórios. Agravo de Instrumento 2015.00.2020284-4. Relator Des. Sérgio Rocha. 4ạ Turma Cível. Decisão Unânime. Julgamento em 30 de set. de 2015. Publicado em 14 de out. de 2015. Disponível em: <http://www.tjdft.jus.br/institucional/jurisprudencia> Acesso em 03 de maio de 2017.

GARGARELA, Roberto. As teorias da justiça depois de Rawls: um breve manual de filosofia política. Tradução: Alonso Reis Freire; revisão da tradução Elza Maria Gasparotto; revisão técnica Eduardo Appio. São Paulo: WMF Martins Fontes, 2008.

GODOI, Marciano Seabra. Justiça, igualdade e direito tributário. São Paulo: Dialética, 1999.

GOMIDE, Alexandre de Ávila. Mobilidade Urbana, Iniqüidade e Políticas Sociais. p. 242-250 In: Instituto de Pesquisas Econômica Aplicada - IPEA. Políticas Sociais -Acompanhamento e Análise. Brasília, 2016.

GRAU, Eros Roberto. Parecer. São Paulo, 23 de nov. de 2015. Disponível em: $<$ http://s.conjur.com.br/dl/parecer-eros-grau-ilegalidade-Uber.pdf>. Acesso em 03 de maio de 2017.

LIBERATI, Wilson Donizeti. Políticas Públicas no Estado Constitucional. São Paulo: Atlas, 2013.

LIMA, Simone Alvarez. A Constitucionalidade do serviço da Uber à luz dos princípios da ordem econômica. Revista da Faculdade de Direito de São Bernardo do Campo. v. 22, n. 01, jan./jul 2016.

OLMOS, Olívia Martins de Quadros e FAVERA, Rafaela Bolson Dalla. Uber x Táxi: Estudo normativo, doutrinário e jurisprudencial acerca do conflito existente entre ambos os serviços de transporte no Brasil. p. 426-450. In: COSTA, Marli Marlene Moraes da e LEAL, Mônica Clarissa Hennig (Orgs.) Políticas públicas e demandas sociais: Diálogos Contemporâneos I. (livro eletrônico) Porto Alegre: Imprensa Livre, 2016.

PINTO, Luzia Marques da Silva Cabral. Os Limites do Poder Constituinte e a Legitimidade Material da Constituição. Coimbra: Coimbra Editora, 1994. 
RAWLS, John. Uma Teoria da Justiça. Tradução Jussara Simões; revisão técnica e da tradução: Álvaro de Vita. 4. ed. rev. São Paulo: Martins Fontes, 2016.

REINO UNIDO. Employment Tribunals. Caso no 2202550/2015. Requerentes Y. Aslam, J. Farrar e Outros. Reclamadas: Uber B. V., Uber London Ltd., e Uber Britannia Ltd. 28 de out. de 2016. Disponível em <https://www.judiciary.gov.uk/wp-content/uploads/2016/10/aslam-and-farrar-vUber-employment-judgment-20161028-2.pdf>. Acesso em 21 de junho de 2017.

RIO DE JANEIRO. Tribunal de Justiça do Estado do Rio de Janeiro. Apelação Cível e Remessa Necessária 0381371-80.2015.8.19.0001. Relator Des. Gabriel de Oliveira Zefiro. 13a Câmara Cível. Decisão unânime. Julgamento em 22 de fev. de 2017. Disponível em: <http://www4.tjr.jus.br/EJURIS/ImpressaoConsJuris.aspx?CodDoc=3348627\&PageSeq=1>.

Acesso em 03 de maio de 2017.

UNIÃO EUROPEIA. Tribunal de Justiça da União Europeia. Parecer do Advogado-Geral Maciej Szpunar. Caso no C-434/15. Requerentes: Asociación Profesional Elite Taxi. Requerida: Uber Systems Spain SL. 11 de maio de 2017. Disponível em <http://curia.europa.eu/juris/document/document.jsf;jsessionid=9ea7d0f130d572e35b505c99 40ddbfedcd9ffd192359.e34KaxiLc3eQc40LaxqMbN4PaxqLe0?text=\&docid=190593\&pagelndex $=0 \&$ doclang $=E N \&$ mode $=I s t \& d i r=\& o c c=$ first $\&$ part $=1 \& c i d=734489>$. Acesso em 21 de junho de 2017.

Trabalho enviado em 03 de maio de 2017.

Aceito em 03 de setembro de 2017. 